\title{
ANALISIS KANDUNGAN KARBOHIDRAT, GLUKOSA, DAN UJI DAYA TERIMA PADA NASI BAKAR, NASI PANGGANG, DAN NASI BIASA
}

Analysis of Carbohydrate, Glucose Content, and Organoleptic Test on The Grilled Rice, Baked Rice, and Ordinary Rice

\author{
Kana Satria Arif Mukti ${ }^{1)}$, Ninna Rohmawati ${ }^{1{ }^{1} *}$, Sulistiyani Sulistiyani ${ }^{1)}$ \\ ${ }^{1)}$ Bagian Gizi Kesehatan Masyarakat, Fakultas Kesehatan Masyarakat, Universitas Jember \\ Jalan Kalimantan 37, Jember, 68121 \\ *E-mail: ninna.rohmawati@ gmail.com
}

\begin{abstract}
White rice is the most consumed food by Indonesian people. However, carbohydrate levels in white rice are included in the high glycemic index (73). This makes the white rice less healthy, especially for people with Diabetes Mellitus (DM). Appropriate processing is done to lower carbohydrate and glucose levels in white rice to be more safe to eat, on the contrary is roasting and burning. The purpose of this study was to analyzed the influence and grilling of white rice on carbohydrate, glucose and white rice test after treatment. The research method used was analytic with experimental design (pre-experimental). Sample of acceptance test research from 25 people with DM in Clinic dr. Suherman University of Muhammadiyah Jember. Friedman Test and Wilcoxon Sign Rank Test was used to analyzed, glucose level and analysis used One Way Anova and Post Hoc (Tukey HSD) Test with 5\% confidence level $(\alpha=0,05)$. The results showed that the average of normal rice sugar, grilled rice, and baked rice (X0, X1, and X2) were 39,44\%; $34.84 \%$; and $37.45 \%$. Medium for the average glucose levels (X0,X1, and X2) was 2.07\%; 2.86\%; and 3.38\%. The results were performed to measured energy, aroma and texture, white rice $(p<\alpha$ value). Grilled rice had low carbohydrate levels and could be accessed by diabetes, 72.38 grams of grilled rice $(25.22 \mathrm{~g}$ of carbohydrates and $2.07 \mathrm{~g}$ of glucose) could be consumed 1-3 times a day.
\end{abstract}

Keywords: carbohydrate, glucose, organoleptic test, grilled rice, baked rice, ordinary rice

\section{PENDAHULUAN}

Nasi putih mengandung zat gizi yang sangat dibutuhkan oleh tubuh untuk menunjang kesehatan manusia. Dalam 100 gram nasi mengandung energi $180 \mathrm{kkal}$, protein $3 \mathrm{~g}$, lemak $0,3 \mathrm{~g}$, karbohidrat 39,8 g, serat $0,2 \mathrm{~g}$, abu $0,2 \mathrm{~g}$, kalsium $25 \mathrm{mg}$, fosfor, $27 \mathrm{mg}$, besi $0,4 \mathrm{mg}$, natrium $1 \mathrm{mg}$, tiamin 0,05 $\mathrm{mg}$, dan kalium $38 \mathrm{mg}$ (Mahmud et al., 2009:1). Nasi putih dikatakan makanan pokok bagi masyarakat di Asia, Asia Tenggara, dan khususnya Indonesia. Nasi putih merupakan makanan pokok yang paling banyak dikonsumsi oleh penduduk Indonesia (Widodo, 2015). Nasi dijadikan sebagai pangan pokok utama dan lambang kemakmuran, dengan tingkat partisipasi konsumsi hampir 100\%. Bahkan banyak orang mengatakan bahwa mereka belum makan jika belum mengonsumsi nasi (Kemendag, 2013).

Seiring dengan perkembangan zaman membuat dunia kuliner semakin berkembang pesat. Begitu pula dengan olahan makanan yang berbahan dasar nasi. Beberapa diantaranya adalah nasi bakar dan nasi panggang yang sekarang dapat kita jumpai mulai dari pedagang kaki lima, rumah makan, bahkan olahan nasi ini dapat dibuat sendiri di rumah, karena sudah banyak resep nasi bakar dan nasi panggang yang dapat diakses melalui internet, buku resep makanan, dll. Nasi bakar adalah jenis olahan nasi yang pada umumnya dibungkus dengan daun pisang dan kemudian dibakar. Hal ini membuat nasi bakar memiliki cita rasa dan aroma 
yang khas, sehingga banyak disukai oleh berbagai kalangan (Maharani, 2015).

Proses pemanasan (pembakaran dan pemanggangan) membuat kadar karbohidrat dan glukosa yang ada pada nasi menjadi berkurang. Proses pemanasan akan mengakibatkan terjadinya leaching atau rusaknya molekul pati (Kurniawan et al., 2015). Proses pemanasan dengan suhu yang semakin tinggi akan mengubah bentuk pati menjadi pati yang tergelatinasi sehingga granula pati yang rusak akan semakin banyak (Imanningsih, 2012).

Berkurangnya kadar karbohidrat dan glukosa pada makanan, akan menjadikan makanan menjadi lebih aman dikonsumsi, khususnya penderita DM (Rafanani, 2013). Saat ini masih banyaknya kasus DM. Indonesia masuk ke dalam peringkat 6 angka kejadian DM terbanyak di dunia. Dari data Riskesdas 2013, pada penduduk usia $\geq 15$ tahun di Indonesia didapatkan proporsi dan perkiraan jumlah absolut DM adalah sekitar 12 juta, toleransi glukosa terganggu (TGT) sekitar 52 juta, dan Gula Darah Puasa (GDP) terganggu sekitar 64 juta (Kementerian Kesehatan RI, 2014). Di Jawa Timur khususnya di Kabupaten Jember kasus DM juga masih banyak. Berdasarkan data DM di Dinas Kesehatan Kabupaten Jember terdapat 9993 kasus pada tahun 2016, 4815 adalah kasus baru serta terdapat 11 kasus meninggal dunia (Dinas Kabupaten Jember, 2016).

Berdasarkan uraian diatas kebiasaan orang Indonesia adalah makan nasi. Perlakuan pemanasan pada nasi (pembakaran dan pemanggangan) dapat membuat kadar karbohidrat dan glukosa pada nasi menjadi berkurang. Dengan adanya penurunan kadar karbohidrat dan glukosa diharapkan nasi akan lebih aman untuk dikonsumsi, khususnya bagi penderita Diabetes Mellitus (DM).

\section{METODE PENELITIAN}

\begin{abstract}
Alat dan Bahan
Alat-alat yang digunakan dalam penelitian ini adalah magic com (merk Cosmos) untuk menanak nasi, timbangan makanan untuk meninggang nasi, tungku pembakaran untuk membakar nasi, oven merk National untuk memanggang nasi, termometer untuk mengukur suhu arang, sedangkan alat yang digunakan untuk analisa antara lain timbangan digital, labu erlenmer, buret, dan statif. Bahan yang digunakan dalam pembuatan nasi bakar dan nasi panggang adalah nasi yang diolah dari beras merk Du'Anak (CV. Dua Putra, Kalisat, Jember).
\end{abstract}

\section{Tahapan Penelitian}

\section{Pembuatan Nasi Bakar}

Nasi \pm 300 gram dimasak dengan air $\pm 0,6$ liter dalam magic com. Setelah nasi matang kemudian nasi ditimbang dengan timbangan makanan \pm 100 gram. Setelah ditimbang kemudian nasi dibungkus dengan daun pisang dan ditusuk dengan lidi di bagian pinggirnya agar bungkusan tidak lepas. Tungku pembakaran disiapkan dan bara api dari arang dihidupkan. Suhu arang diperiksa dengan termometer sampai suhu $\pm 180^{\circ} \mathrm{C}$. Margarin/minyak goreng dioleskan pada bungkusan daun pisang. Nasi yang telah dibungkus daun pisang (dua lembar) dibakar \pm 10 menit, sampai daun pisang layu dan berubah warna kering kecoklatan (Dundu et al., 2012).

\section{Pembuatan Nasi Panggang}

Nasi \pm 300 gram dimasak dengan air $\pm 0,6$ liter dalam magic com. Setelah nasi matang kemudian nasi ditimbang dengan timbangan makanan \pm 100 gram, kemudian nasi dibungkus dengan daun pisang dan ditusuk dengan lidi di bagian pinggirnya agar bungkusan tidak lepas. Panggangan (oven) disiapkan dan ditunggu sampai suhu stabil. Margarin/minyak goreng dioleskan pada bungkusan daun pisang. Nasi yang telah dibungkus daun pisang 
(dua lembar) dipanggang dengan suhu $\pm 180^{\circ} \mathrm{C}$ selama \pm 25 menit, sampai daun pisang mulai layu dan berubah warna menjadi kering kecoklatan.

\section{Rancangan Percobaan}

Penelitian ini merupakan jenis penelitian (Pre-Eksperimental) menggunakan desain One Group PretestPostest, dalam rancangan ini pengukuran dilakukan sebelum (X0) dan sesudah perlakuan (X1 dan X2) atau intervensi yang telah dilakukan (X) (Sugiyono, 2015). Jumlah satuan unit percobaan adalah 3 taraf perlakuan $\mathrm{x} 4$ replikasi $=12$ unit percobaan. Secara umum ulangan (replications) minimal untuk percobaan laboratorium cukup tiga kali (Hanafiah, 2005).

\section{Metode Analisis}

Produk nasi diujikan secara organoleptik dengan 25 panelis tidak terlatih. Pengujian analisis meliputi uji organoleptik dan uji kimia (karbohidrat dan glukosa). Parameter uji organoleptik meliputi warna, tekstur, rasa, dan aroma. Pengujian menggunakan metode hedonic scale test dengan analisa uji Friedman. Jika terdapat beda nyata terhadap produk maka dilanjutkan dengan uji Wilcoxon Sign Rank Test. Untuk kadar karbohidrat dan glukosa dianalisis menggunakan uji One Way Anova dan Post Hoc Tests (Tukey HSD) dengan tingkat kepercayaan $5 \%(\alpha=0,05)$. Uji kimia (karbohidrat dan glukosa) dilakukan pada nasi sebelum (X0) dan sesudah perlakuan (X1 dan X2) menggunakan metode (Direct Acid Hydrolysys Method: AOAC dalam Nurhidajah et al., 2015).

\section{HASIL DAN PEMBAHASAN}

\section{Analisis Kadar Karbohidrat Nasi Bakar, Nasi Panggang, dan Nasi Biasa \\ Karbohidrat merupakan zat gizi sumber energi paling penting bagi makhluk hidup. Kadar karbohidrat dinyatakan dalam bentuk \% per 100 gram bahan (Gambar 1).}



Gambar 1. Kadar karbohidrat pada nasi biasa (X0), nasi bakar (X1), dan nasi panggang (X2)

Gambar 1 menunjukkan bahwa kadar karbohidrat nasi biasa, nasi bakar, dan nasi panggang (X0, X1, dan X2) yaitu 39,44; 34,84; dan 37,45. Berdasarkan uji normalitas Shapiro-Wilk didapatkan hasil nilai sig. (X0, X1, dan X2) >0,05 yaitu $0 ; 312, \quad 0 ; 584 ;$ dan $0 ; 792$ yang menunjukkan data berdistribusi normal. Kemudian berdasarkan uji homogenitas varian didapatkan hasil sig. >0,05 yaitu 0,350 yang artinya data bersifat homogen. Berdasarkan syarat tersebut maka dapat dilakukan uji One Way Anova dengan tingkat signifikasi $(\alpha)$ sebesar 0,05 dan didapatkan nilai $p$ value 0,000 menunjukan adanya perbedaan yang signifikan dari perlakuan berupa pembakaran dan pemanggangan terhadap kadar karbohidrat nasi. Berdasarkan Post Hoc Tests (Tukey $H S D)$ didapatkan hasil bahwa perbandingan antara dua kelompok perlakuan menunjukkan perbedaan yang signifikan dengan $p$ value $\leq 0,05$. 
Tabel 1. Hasil post hoc tests (tukey HSD) terhadap kadar karbohidrat nasi

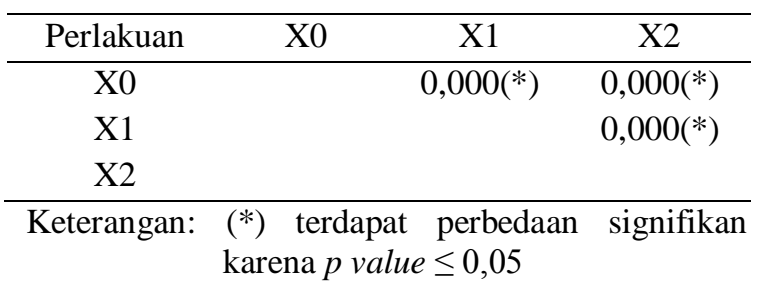

Kadar karbohidrat mulai tertinggi hingga terendah terkandung dalam nasi biasa (X0), kemudian nasi panggang (X2) dan nasi bakar (X1) (Gambar 1). Terlihat bahwa proses pemanasan, berupa pembakaran (X1), dan pemanggangan (X2) sama-sama membuat kadar karbohidrat pada nasi mengalami penurunan. Hal ini sejalan dengan penelitian yang dilakukan oleh Kurniawan yang menyatakan bahwa pemanasan akan mengakibatkan terjadinya leaching atau rusaknya molekul pati (Kurniawan, 2015). Heryanti et al. (2014) menyatakan bahwa pemanasan akan menyebabkan terjadinya penurunan kadar pati. Peningkatan suhu mengakibatkan komponen amilosa penyusun pati merupakan amilosa dengan bobot molekul rendah. Amilosa yang sudah terbentuk mengalami depolimerisasi pada pemanasan suhu tinggi sehingga amilosa memiliki bobot molekul rendah, amilosa pada fraksi 2 (bobot molekul rendah) nilai $\%$ sineresisnya semakin tinggi (Heryanti et al., 2014). Proses pemanasan dengan suhu yang semakin tinggi akan mengubah bentuk pati menjadi pati yang tergelatinasi sehingga granula pati yang rusak akan semakin banyak. Jumlah fraksi amilosa-amilopektin juga sangat berpengaruh pada profil gelatinisasi pati. Amilosa memiliki ukuran yang lebih kecil dengan struktur tidak bercabang. Sementara amilopektin merupakan molekul berukuran besar dengan struktur bercabang banyak dan membentuk double helix. Saat pati dipanaskan, beberapa double helix fraksi amilopektin merenggang dan terlepas saat ada ikatan hidrogen yang terputus (Imanningsih, 2012).

\section{Analisis Kadar Glukosa Nasi Bakar, Nasi Panggang, dan Nasi Biasa}

Kadar Glukosa menjadi salah satu indikator dalam penelitian ini. Kadar glukosa nasi dalam 100 gram bahan dapat dilihat pada Gambar 2.



Gambar 2. Kadar Glukosa pada nasi biasa (X0), nasi bakar (X1), dan nasi panggang (X2)

Gambar 2 menunjukkan bahwa kadar glukosa nasi biasa, nasi bakar, dan nasi panggang (X0, X1, dan $\mathrm{X} 2$ ) yaitu 2,07; 2,86; dan 3,38. Berdasarkan uji normalitas (Shapiro-Wilk) didapatkan hasil nilai sig. (X0, X1, dan X2) >0,05 yaitu $0 ; 616, \quad 0 ; 925 ;$ dan $0 ; 467$ yang menunjukkan data berdistribusi normal. Kemudian berdasarkan uji homogenitas varian didapatkan hasil sig. >0,05 yaitu 0,476 yang artinya data bersifat homogen. Berdasarkan syarat tersebut maka dapat dilakukan uji One Way Anova dengan tingkat signifikasi $(\alpha)$ sebesar 0,05 dan didapatkan nilai $p$ value 0,000 menunjukan adanya perbedaan yang signifikan dari perlakuan berupa pembakaran dan pemanggangan terhadap kadar glukosa nasi. Berdasarkan Post Hoc Tests (Tukey $H S D)$ didapatkan hasil bahwa perbandingan antara dua kelompok perlakuan menunjukkan perbedaan yang signifikan dengan $p$ value $\leq 0,05$. 
Tabel 2. Hasil post hoc tests (Tukey HSD) terhadap kadar glukosa nasi

\begin{tabular}{cccc}
\hline Perlakuan & X0 & X1 & X2 \\
\hline X0 & & $0,000(*)$ & $0,000\left(^{*}\right)$ \\
X1 & & & $0,000\left(^{*}\right)$ \\
X2 & & &
\end{tabular}

Keterangan: $\left(^{*}\right)$ terdapat perbedaan signifikan karena $p$ value $\leq 0,05$

Kadar glukosa mulai tertinggi hingga terendah terkandung dalam nasi panggang (X2), nasi bakar (X1), dan nasi biasa (X0) (Gambar 2). Terlihat bahwa proses pemanasan, berupa pembakaran (X1) dan pemanggangan (X2) sama-sama membuat kadar glukosa pada nasi mengalami kenaikan. Hal ini sejalan dengan penelitian yang dilakukan oleh Wahyudi et al. (2011) yang menyatakan bahwa semakin tinggi suhu reaksi $\left(29^{\circ} \mathrm{C}\right.$, $60^{\circ} \mathrm{C}, 101^{\circ} \mathrm{C}$ ), makin cepat pula jalannya reaksi. Kadar glukosa akan naik seiring dengan bertambahnya suhu. Hal ini dikarenakan reaksi hidrolisis merupakan reaksi endotermis sehingga memerlukan panas untuk dapat bereaksi. Tetapi, jika suhu terlalu tinggi, maka katalis $(\mathrm{HCl})$ akan menguap yang mengakibatkan melambatnya reaksi hidrolisis tersebut yang juga akan berakibat pada konsentrasi glukosa yang diperoleh. Hasil penelitian juga menunjukkan bertambahnya waktu reaksi mengakibatkan glukosa yang terbentuk semakin banyak. Kondisi ini terjadi pada semua perlakuan variasi suhu. Ketika kenaikan glukosa cenderung mulai konstan, hal ini menunjukkan reaktan sudah hampir terkonversi semua menjadi glukosa (Wahyudi et al., 2011). Juga sejalan dengan penelitian yang dilakukan oleh Nilasari et al. (2017) yang menyatakan bahwa kenaikan kadar gula seiring dengan kenaikan suhu $\left(70^{\circ} \mathrm{C}, 80^{\circ} \mathrm{C}\right.$, $\left.90^{\circ} \mathrm{C}\right)$ dan semakin lama pemasakan $(90$ menit, 120 menit, 150 menit). Hal ini terjadi karena semakin lama pemasakan dan semakin tinggi suhu yang digunakan akan menyebabkan terjadinya proses penguapan air yang semakin tinggi pula.
Semakin tinggi penguapan air yang terjadi akan menyebabkan penurunan kadar air yang berakibat pada kenaikan persentase total gula (Nilasari et al., 2017).

\section{Analisis Daya Terima Nasi Bakar, Nasi Panggang, dan Nasi Biasa \\ Rasa}

Analisis sensori terkait rasa sangat penting karena selera manusia sangat menentukan dalam penerimaan dan nilai suatu produk. Perlakuan yang memiliki nilai rasa tertinggi berdasarkan penilaian panelis yaitu pada perlakuan X2 (pemanggangan). Perlakuan dengan nilai terendah adalah perlakuan X1 (pembakaran) (Gambar 3).



Gambar 3. Penilaian panelis dengan hedonic scale test terhadap rasa nasi biasa $(\mathrm{X} 0)$, nasi bakar (X1), dan nasi panggang (X2)

Berdasarkan hasil analisis menggunakan uji Friedman didapatkan $p$ value sebesar 0,573 sehingga $\mathrm{H}_{0}$ diterima, yang berarti tidak terdapat perbedaan yang signifikan dari perlakuan pembakaran dan pemanggangan terhadap daya terima rasa nasi. Hal ini dikarenakan tidak adanya penambahan bahan lain selain bahan dasar berupa nasi. Oleh karena itu perlakuan pembakaran dan pemanggangan tidak berpengaruh secara signifikan terhadap rasa nasi.

\section{Warna}

Warna menandakan rasa suatu bahan pangan. Perlakuan yang memiliki nilai tertinggi yaitu perlakuan X2 (pemanggangan) berdasarkan hasil uji Hedonic Scale Test. Perlakuan terendah 
adalah perlakuan X1 (pembakaran) pada Gambar 4.

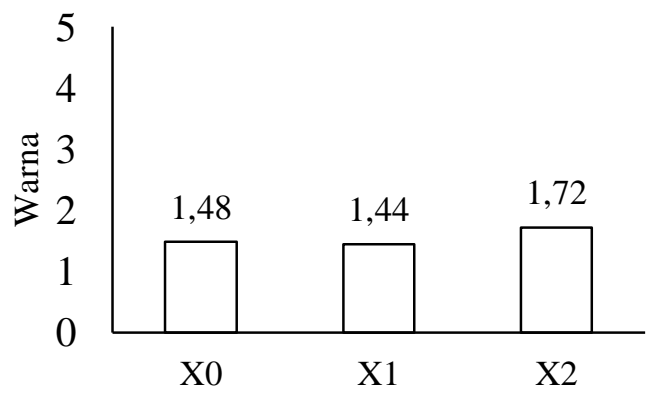

Gambar 4. Penilaian panelis dengan hedonic scale test terhadap warna nasi biasa (X0), nasi bakar (X1), dan nasi panggang (X2)

Berdasarkan hasil analisis menggunakan uji Friedman didapatkan $p$ value sebesar 0,225 sehingga $\mathrm{H}_{0}$ diterima, yang berarti tidak terdapat perbedaan yang signifikan dari perlakuan pembakaran dan pemanggangan terhadap daya terima warna nasi. Hal ini dikarenakan tidak adanya penambahan bahan lain selain bahan dasar berupa nasi. Oleh karena itu perlakuan pembakaran dan pemanggangan tidak berpengaruh secara signifikan terhadap warna nasi.

\section{Aroma}

Berdasarkan hasil uji Hedonic Scale Test, perlakuan yang memiliki nilai aroma tertinggi yaitu pada perlakuan X2 (pemanggangan), sedangkan perlakuan dengan nilai terendah adalah perlakuan $\mathrm{X} 1$ (pembakaran). Nilai aroma berdasarkan penilaian panelis dapat dilihat pada Gambar 5.



Gambar 5. Penilaian panelis dengan hedonic scale test terhadap aroma nasi biasa (X0), nasi bakar (X1), dan nasi panggang (X2)

Berdasarkan hasil analisis menggunakan uji Friedman didapatkan $p$ value sebesar 0,009 sehingga $\mathrm{H}_{0}$ ditolak, yang berarti terdapat perbedaan yang signifikan dari perlakuan pembakaran dan pemanggangan terhadap daya terima aroma nasi. Uji dilajutkan dengan Wilcoxon Sign Rank Test.

Tabel 3. Hasil uji wilcoxon sign rank test terhadap daya terima aroma nasi

\begin{tabular}{cccc}
\hline Perlakuan & X0 & X1 & X2 \\
\hline X0 & & 0,084 & 0,427 \\
X1 & & & $0,022(*)$ \\
X2 & & & \\
Keterangan: & $\begin{array}{l}\left(^{*}\right) \\
\text { karena } p \text { value }\end{array}$ & terdapat & perbedaan \\
& signifikan & \\
&
\end{tabular}

Perbedaan secara nyata terlihat ketika dilakukan uji Wilcoxon Sign Rank Test yaitu antara perlakuan berupa pembakaran (perlakuan X1) dengan pemaggangan (perlakuan X2). Nasi dengan perlakuan berupa pemanggangan lebih disukai oleh para panelis. Menurut Kariada et al. (2014) masakan yang dihasilkan pada proses pemanggangan lebih merata matangnya. Panas pada oven dihasilkan oleh plat logam dari segala arah, sehingga aroma khas yang dihasilkan dari daun pisang sebagai pembungkus nasi lebih lebih terasa. Sedangkan pada nasi bakar (perlakuan X1) mendapatkan nilai paling rendah diantara perlakuan yang diberikan. Hal ini terjadi karena dalam 
proses pembakaran, panas yang dihasilkan tidak merata, atau hanya dari bawah panggangan saja. Selain itu bahan bakar yang digunakan adalah arang yang banyak mengandung karbon. Oleh karena itu aroma yang dihasilkan pada nasi bakar adalah aroma carbon dari arang dan bau sangit dari daun pisang itu sendiri.

\section{Tekstur}

Tekstur didefinisikan sebagai sifat bahan makanan yang dideteksi oleh mata, kulit dan otot-otot mulut, termasuk di dalamnya sifat kasar, sifat halus, sifat berpasir dan sebagainya. Berdasarkan hasil uji Hedonic Scale Test, perlakuan yang memiliki nilai tertinggi yaitu pada perlakuan X1 (pembakaran), sedangkan perlakuan dengan nilai terendah adalah perlakuan X0 (nasi biasa) (Gambar 6).

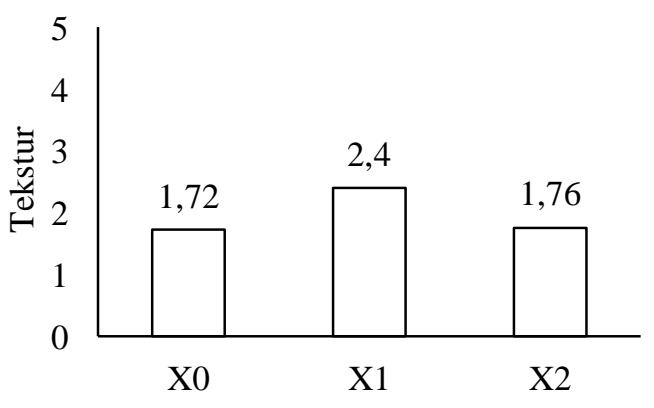

Gambar 6. Penilaian panelis dengan hedonic scale test terhadap tekstur nasi biasa (X0), nasi bakar (X1), dan nasi panggang (X2)

Berdasarkan hasil analisis menggunakan uji Friedman didapatkan $p$ value sebesar 0,027 sehingga $\mathrm{H}_{0}$ ditolak, yang berarti terdapat perbedaan yang signifikan dari perlakuan pembakaran dan pemanggangan terhadap daya terima aroma nasi. Uji selanjtnya yaitu Wilcoxon Sign Rank Test.
Tabel 4. Hasil uji wilcoxon sign rank test terhadap daya terima aroma nasi

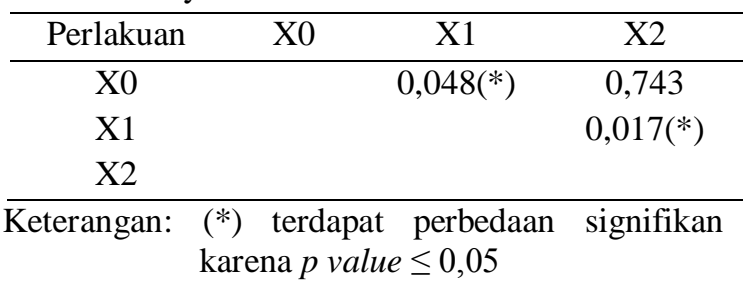

Perbedaan secara nyata terlihat ketika dilakukan uji Wilcoxon Sign Rank Test yaitu antara perlakuan berupa pembakaran (perlakuan X1) dengan nasi biasa (perlakuan X0) dan pemaggangan (perlakuan X2) dengan pembakaran (perlakuan X1). Nasi dengan perlakuan berupa pembakaran (perlakuan X1) lebih disukai karena nasi yang dibakar dengan suhu $\pm 180^{\circ} \mathrm{C}$ dengan waktu 10 menit, membuat kadar air yang ada di dalam nasi sedikit berkurang, sehingga terkstur nasi sedikit lebih pera/ keras. Sedangkan nasi biasa (perlakuan X0) mendapatkan nilai terendah dikarenakan kandungan air yang ada di dalam nasi masih banyak dan hal ini membuat tekstur nasi menjadi sedikit lembek. Menurut Purwani (2006), tingkat kesukaan terhadap mutu nasi untuk tiap penduduk didaerah berbeda-beda. Pada penelitian ini panelis $84 \%$ terdiri dari lansia. Beras yang mempunyai nilai tingkat penerimaan yang tinggi umumnya memiliki kadar amilosa rendah sampai sedang (17-25\%). Beras yang mempunyai nilai penerimaan rendah mengandung amilosa tinggi (>25\%). Dengan demikian semakin rendah amilosa, semakin tinggi mutu penerimaanya (Purwani, 2006).

\section{Analisis Kadar Karbohidrat, Glukosa, dan Daya Terima Nasi Bakar, Nasi Panggang, dan Nasi Biasa}

Pengaruh perlakuan berupa pembakaran dan pemanggangan didapatkan hasil yang signifikan terhadap kadar karbohidrat nasi. Kadar karbohidrat berdasarkan hasil hitung mengalami penurunan paling tinggi adalah perlakuan berupa pembakaran (perlakuan X1) yaitu 
sebesar 4,6\% (39,44\% menjadi 34, 84\%), sedangkan untuk perlakuan berupa pemanggangan (perlakuan X2) mengalami penurunan sebesar $1,99 \%(39,44$ menjadi 37,45). Dengan jumlah porsi yang sama (100 gram nasi), kadar karbohidrat yang rendah lebih direkomendasikan bagi penderita DM. Karena semakin sedikit jumlah karbohidrat yang masuk ke dalam tubuh, maka semakin sedikit pula glukosa yang akan terbentuk di dalam tubuh.

Pengaruh perlakuan berupa pembakaran dan pemanggangan juga didapatkan hasil yang signifikan terhadap kadar glukosa pada nasi. Kadar glukosa berdasarkan hasil hitung mengalami kenaikan paling tinggi adalah perlakuan berupa pemanggangan (perlakuan X2) yaitu sebesar $1,31 \% \quad(2,07 \%$ menjadi $3,38 \%$ ), sedangkan untuk perlakuan berupa pembakaran (perlakuan X1) mengalami kenaikan sebesar 0,79\% (2,07\% menjadi 2,86\%). Kadar Glukosa yang tinggi pada makanan akan dengan mudah menaikan kadar glukosa darah, sehingga kadar glukosa yang sedikit dalam nasi lebih aman dikonsumsi bagi penderita DM.

Terdapat perbedaan yang nyata dari perlakuan berupa pembakaran dan pemanggangan terhadap daya terima (aroma dan tesktur) yang dinyatakan pada hasil uji Friedman. Berdasarkan penilaian dengan uji Wilcoxon Sign Rank Test untuk daya terima aroma antara kelompok sebelum perlakuan (X0) dengan kelompok perlakuan (X1 dan X2) tidak terdapat perbedaan yang nyata. Tapi terdapat perbedaan signifikan antara (X1 dan X2) dengan $p$ value 0,022 . Daya terima tekstur terdapat perbedaan yang nyata antara X0 dan $\mathrm{X} 1$ dengan $p$ value 0,048. Namun untuk daya terima (rasa dan warna) tidak terdapat perbedaan yang nyata. Berdasarkan penilaian Hedonic Scale Test rasa, yang memiliki nilai tertinggi adalah nasi panggang (perlakuan X2), warna yang tertinggi nasi panggang (perlakuan X2), aroma yang tertinggi nasi panggang (perlakuan X2), dan tekstur yang tertinggi nasi bakar (perlakuan X1).

Berdasarkan uraian diatas, maka nasi yang disarankan adalah nasi dengan perlakuan berupa pembakaran. Hal ini disebabkan karena nasi bakar memiliki kandungan karbohidrat yang rendah dan kandungan glukosa yang tidak terlalu tinggi, selain itu untuk daya terima tekstur nasi bakar paling disukai oleh panelis. Dalam uji daya terima (rasa, aroma, dan warna) walaupun nasi yang memiliki daya terima yang paling tinggi adalah nasi panggang namun kadar glukosa pada nasi mengalami kenaikan yang cukup tinggi, yaitu 1,31 atau $63,28 \%$ dari glukosa nasi biasa. Aspek yang paling penting adalah kandungan karbohidrat dan glukosa yang rendah pada makanan lebih direkomendasikan untuk penderita DM khususnya dan untuk pencegahan DM pada umumnya. Sebanyak 72,38 gram nasi bakar (25,22 g Karbohidrat dan 2,07 g Glukosa) dapat dikonsumsi 1-3 kali sehari.

\section{KESIMPULAN}

Kadar karbohidrat, glukosa dan uji daya terima (aroma dan tekstur) antara nasi bakar, nasi panggang dan nasi biasa memiliki perbedaan signifikan $(\alpha=5 \%)$. Namun untuk uji daya terima rasa dan warna tidak terdapat perbedaan yang signifikan. Nasi yang direkomendasikan adalah nasi bakar, karena nasi bakar memiliki kadar karbohidrat yang rendah dan dapat diterima oleh penderita DM, sehingga 72,38 gram nasi bakar $(25,22 \mathrm{~g}$ Karbohidrat dan 2,07 g Glukosa) dapat dikonsumsi 1-3 kali sehari.

\section{UCAPAN TERIMA KASIH}

Ucapan terimakasih ditujukan kepada Klinik dr. Suherman yang telah bersedia menyediakan panelis (25 pasien DM) untuk uji daya terima nasi, dan Laboratorium Analisis Pangan Politeknik Negeri Jember yang telah membantu menganalisis kadar (karbohidrat dan glukosa). 


\section{DAFTAR PUSTAKA}

Dinas Kesehatan Kabupaten Jember. 2016. Data Diabetes Kabupaten Jember Tahun 2013-2016. Dinas Kesehatan, Jember.

Dundu, P. L., Ninik, F. R., Nusrat, M. 2012. Kenikmatan dari sebungkus nasi bakar. http://travel.kompas.com/read/2012/03/07 /07480623/Kenikmatan.dari.Sebungkus. Nasi.Bakar. [Diakses tanggal 2 September 2017]

Hanafiah, K. A. 2005. Rancangan Percobaan Aplikatif. Raja Grafindo Persada, Jakarta.

Heryanti, P., Setyawati, R., Wicaksono, R. 2014. Pengaruh suhu dan lama pemanasan suspensi pati serta konsentrasi butanol terhadap karakteristik fisikokimia pati tinggi amilosa dari tapioka. Jurnal Agritech, 34 (3): 308-315

Imanningsih, N. 2012. Profil gelatinisasi beberapa formulasi tepung-tepungan untuk pendugaan sifat pemasakan. Penelitian Gizi Makanan 2012, 35 (1): 13-22.

Kariada, T., Rosidah, Saputro, D. Oven Panggang Sebagai Solusi Pengolahan Ikan Higienis Dan Ramah Lingkungan. Jurnal Rekayasa. 12 (2): 1-9.

Kementerian Kesehatan RI. 2014. Situasi dan Analisis Diabetes. (http://www.depkes.go.id/). [Diakses Tanggal 30 Mei 2017].

Kementerian Perdagangan RI. 2013. Laporan Akhir Analisis Dinamika Konsumsi Pangan Masyarakat Indonesia. (http://www.kemendag.go.id). [Diakses Tanggal 26 Oktober 2017].

Kurniawan, F., Hartini, S., Hastuti, D. 2015. Pengaruh Pemanasan Terhadap Kadar Pati Dan Gula Reduksipada Tepung Biji Nangka(Artocarpus Heterophyllus Lamk). Prosiding Seminar Nasional Sains dan Pendidikan Sains $X$. BI/KI/MA. 1-10.

Maharani, S. 2015. Nasi Bakar Organik Tanpa Vetsin yang Disukai Dahlan Iskan. (https://travel.tempo.co/read/news/2015). [Diakses tanggal 30 Agustus 2017].
Mahmud, M. K., Hermana, Zulfianto, N. A., Roanna, R., Apriyantono, Ngadiarti, I., Hartati, B., Bernadus dan Tinexcelly. 2009. Tabel Komposisi Pangan Indonesia (TKPI). PT Elex Media Komputindo, Jakarta.

Nilasari, O., Susanto, W., Maligan, J. 2017. Pengaruh Suhu dan Lama Pemasakan Terhadap Karakteristik Lempok Labu Kuning (WALUH). Jurnal Pangan dan Agroindustri, 5 (3): 15-26.

Nurhidajah, Astuti, Sardjono, Murdiati, dan Marsono. 2015. "Kadar Serat Pangan dan Daya Cerna Pati Nasi Merah yang Dipekaya Kappa-karagenan dan ekstrak Antosianin dengan Variasi Metode pengolahan". The 2nd University Research Coloqium 2015. Program Studi Teknologi Pangan FIKKES Universitas Muhammadiyah Semarang, Semarang.

Nurhidajah, Astuti, Sardjono, Murdiati, dan Marsono. 2015. "Kadar Serat Pangan dan Daya Cerna Pati Nasi Merah yang Dipekaya Kappa-karagenan dan ekstrak Antosianin dengan Variasi Metode pengolahan". The 2nd University Research Coloqium 2015. Program Studi Teknologi Pangan FIKKES Universitas Muhammadiyah Semarang, Semarang.

Purwani E.Y., Widaningrum, Thahrir R dan Muslich. 2006. Effect of moisture treatment of sago starch on its noodle quality. Indonesian J. Agr. Sci., 7: 8-14.

Rafanani, B. 2013. Buku Pintar Pola Makan Sehat \& Cerdas Bagi Penderita Diabetes. Araska, Yogyakarta.

Robifhinisiawati, E. 2012. "Perbandingan Kadar Glukosa dan Uji Daya Terima Produk Olahan Makanan dengan Bahan Dasar Kentang dan Ubi Jalar". Skripsi. Program Studi Pendidikan Biologi Fakultas Keguruan dan Ilmu Pendidikan Universitas Muhamadiyah Surakarta.

Wahyudi, J., Wibowo, W., Rais, Y., Kusumawardani, A. 2011. Pengaruh Suhu Terhadap Kadar Glukosa Terbentuk dan Konstanta Kecepatan Reaksi pada Hidrolisa Kulit Pisang. Prosiding Seminar Nasional Teknik Kimia "Kejuangan". B09 : 1-5. 
Widodo. 2015. Manfaat dan Komposisi

Kandungan Nutrisi dan Gizi Nasi.

(https://klinikgizi.com). [Diakses tanggal

17 Juli 2017]. 